This will lead to a modification of some of the views advanced in my census report above referred to, concerning the past geological history of the peninsula, and the origin of the high hummocks; for these hummocks, in part at least, are produced by the action of the miocene phosphatic limestone, and not the oligocene, upon the prevailing sandy soils.

And, similarly, the much wider distribution of these miocene rocks proves that a much larger proportion of the peninsula was submerged after the oligocene period than I at one time supposed.

We shall look with the very greatest interest for the results of Mr. Johnson's investigations of the rocks of the western coast of Florida, in Hernando and Hillsborough counties.

I may add that none of the specimens of the upper oligocene or Vicksburg limestone, either from Florida or Alabama, which I have examined, show more than a slight trace of phosphoric acid.

University of Alabama, April 20.

Eugene A. Smith.

It might have been hasty, without books, and without sufficient opportunity for comparison, to have pronounced the phosphatic rocks of Preston's Sink, Fort Harlee, miocene, or not older. I now think it later still; but always with the reservation that $\mathbf{I}$ may be permitted to change my mind upon a more careful study, under circumstances more favorable, and also deferring to the opinion of Dr. White, who already has such favorable opportunities, when he can get time to take up the subject, with all my collection before him.

The location of these phosphates is of more immediate import to you and me. But, on the question of the horizon, I ask the consideration of the facts and specimen already sent you. The 'Nigger Sink' at Downing's, in this vicinity alone, ought to set the question at rest. 1 There you find in situ, and exhibiting their due relations, the oligocene limestone at the base, and finally, after various intermediate deposits, a hundred and fifty feet above, the siliceous phosphatic rock, exactly similar to that sent you from the quarry at Gainesville, from Liveoak, and which is found in this oak and hickory region on the top of every hill.

There, also, you find two fossils, - the Ostrea, found also at Hawthorne and in the Wacahootie region, Marion county, always underlying the phosphates, and above the Orbitoides and Pecten of the limestone; and the other, the great coralline, of which I could mail but a fragment. This last is seen in situ, so far as I am now informed, nowhere but on the tops of these hills, overlooking the Natural Bridge of Santa Fé.

The Furt Harlee marl, near Waldo, is quite different from the phosphatic rock I have been sending you from so many points. It has all its shells, or casts of shells, intact. The vertebrate fossils, however, seem the same; that is, the sharks' teeth and saurian remains are alike. The phosphatic rock has lost all its fossil shells. That these once existed, is clear from the fact that occasionally a trace may be found. If not the same, then how are they related? The argument must be postponed; but to me the conclusion is clear that the Waldo bed is newer than the others. All the others, from the texture of the rock, the obscure traces of shells, the chemical constituents, and from the surroundings, may be classed as one.

1 Three others, heretofore explained, - Simmons at Haw. thorne, Sullivan old field, and the devil's mill-hopper, - sustain the same conclusions, and none contradict.
The great extent of the formation, and the uniformity of the rock, are still very remarkable.

Undoubtedly it is the same rock seen near Ocala, where the limestone is not visible, at Hawthorne, at Gainesville, at Newmanville, at two or three knolls in the vicinity of Liveoak, and on innumerable others all over this central region of oligocene sinks. Strangely, too, the knobs are uniformly of a height of about sixty feet above the surrounding flats and depressions marked by the cherty limestone. It would be interesting and valuable, if I had the means in my power, to locate and measure the extent of every one of these deposits. Your own census report, giving the extent of hummocks, and oak and hickory soils, east of the great chain of sand-dunes from Apopka northward, and west of the lake region, is the nearest means I can suggest for making an approximate estimate.

Newmanville, Fla., March 22.

AURENCE C. JOHNSON.

\section{Do telegraph-wires foretell storms?}

Probably some thousand Americans have noticed the automatic storm-signalling of wires by soundvibration. I allowed a telephone-wire to remain for a long time attached to one corner of my (frame) house because of its practical utility as a weather-prophet. When not a leaf was stirring in the neighborhood, and not a breath to be felt, the deep undulations were audible in almost every room, although mufflers had been duly applied. Before that, some hours in advance of every severe storm, the upper story was hardly inhabitable on account of the unearthly uproar, which would have made a first-rate case for the Society for psychical research.

The warning that it gave varied from six to twelve hours, rarely exceeding the latter; and I do not think it ever warned in vain. When the storm actually came, the noise nearly always ceased. It never was noticeable in the warmer part of the year; and through the heat of midsummer it was silent. I cannot recall any exception to this. Its climax of clamor was reached some hours before the 'electric storm,' as it was called, of November, 1882. But all through two winters and the proximate parts of autumn and spring I found it a trustworthy and selfannouncing storm-signaller, which left me abundant time to prepare. I had it removed, finally, because there was sickness in the house, and its doleful prophecies were not appreciated.

I explained the phenomenon, partly at least, by the effect of very distant air-impulses transmitted in sound-waves from wire to wire, after the manner of the acoustic or mechanical telephone. Yet this does not seem quite adequate, when one considers how far those vibrations must have travelled to outstrip a storm by hours; and yet how much energy and sonorousness they retained when they reached me!

Washington, April 16. WM. H. BABCOCK.

[We have good authority for saying that the vibrations of the telephone and telegraph wires here re ferred to are certainly not due to electric currents, nor to the minute acoustic waves of the mechanical telephone, but are simple transverse vibrations and longitudinal waves such as occur on every stretched cord that gives out a musical note. These vibrations are ultimately caused by the wind. For any given wire stretched in a permanent location, there will undoubtedly be a certain direction and character of wind that will call forth its lourlest tones. Our correspondent's wire may be specially influenced by the south- 